\title{
PENGARUH PROSPEK KEUANGAN DAN AUDIT TENURE TERHADAP PENERBITAN OPINI AUDIT GOING CONCERN
}

\author{
Annisa Rahmawati \\ Universitas 45 Surabaya \\ rahmawaty.annisa@gmail.com
}

\section{Achmad Daengs Gatot Soeherman}

Universitas 45 Surabaya

bumigora80@gmail.com

\begin{tabular}{|ll|} 
Diterima & $: 28$ Maret 2020 \\
Direview & $: 19$ Mei 2020 \\
Diterima & $: 2$ Juni 2020 \\
\hline
\end{tabular}

\begin{abstract}
This study aims to provide empirical evidence and analyze the effect of the company's financial prospects (consisting of elements of profitability, liquidity, and solvency) and audit tenure on the issuance of going concern audit opinion. This research is a descriptive quantitative research. The population in this study are companies listing on the Indonesia Stock Exchange in the 2014-2018 period. The sample in this study were companies listing on the IDX during that period and experiencing a downward trend in financial prospects. The data used are secondary data obtained from financial statements from the IDX website. The statistical analysis method for testing hypotheses in this study is logistic regression. From the hypothesis testing conducted, the results of statistical testing of this study indicate that solvency is a factor that significantly influences the giving of going concern audit opinion. This indicates that the higher the solvency ratio, the higher the company's expectations for continuing and the lower the probability for the company to accept going-concern audit opinions.
\end{abstract} Keywords: Liquidity, Profitability, Solvency, Tenure, Goingconcern.

\begin{abstract}
Abstrak
Studi ini bertujuan untuk memberikan bukti empiris dan mengupas mengenai pengaruh prospek keuangan perusahaan (yang terdiri dari elemen profitabilitas, likuiditas, dan solvabilitas) dan audit tenure terhadap penerbitan opini audit going concern. Penelitian ini merupakan penelitian kuantitatif deskriptif. Populasi dalam penelitian ini adalah perusahaan yang listing di BEI periode 2014-2018. Sampel dalam penelitian ini adalah perusahaan yang listing di BEI pada periode tersebut dan mengalami tren penurunan prospek
\end{abstract}


keuangan. Data yang digunakan adalah data data sekunder yang didapatkan dari laporan keuangan dari situs BEI. Metode analisa statistic untuk pengujian hipotesis dalam penelitian ini adalah regresi logistic. Dari pengujian hipotesis yang dilakukan, hasil pengujian statistik dari penelitian ini menunjukkan bahwa solvabilitas merupakan factor yang berpengaruh signifikan terhadap pemberian opini audit going concern. Hal ini mengindikasikan bahwa semakin tinggi rasio solvabilitas, maka semakin tinggi harapan perusahaan untuk tetap berlangsung dan semakin rendah kemungkinan perusahaan untuk menerima opini audit going concern.

\section{Kata Kunci : Likuiditas, Profitabilitas, Solvabilitas, Tenure, Goingconcern.}

\section{PENDAHULUAN}

Laporan keuangan merupakan salah satu alat manajemen untuk mengkomunikasikan informasi keuangan yang berkaitan dengan kegiatan operasional perusahaan kepada para pengguna informasi keuangan, agar dapat menilai kinerja keuangan perusahaan. Laporan keuangan haruslah mencakup informasi yang menyeluruh berkaitan dengan kegiatan ekonomi perusahaan (Simamora \& Hendarjatno, 2019). Sehubungan dengan kebutuhan akan informasi yang obyektif mengenai kondisi ekonomi perusahaan maka dibutuhkan kegiatan yang dapat memberikan opini yang obyektif dan tidak memihak berkaitan dengan posisi keuangan perusahaan yang disebut dengan Audit.

Audit dapat diinterpretasikan sebagai proses pemahaman terhadap informasi keuangan yang kemudian ditandingkan dengan prinsip akuntansi berterima umum dalam tujuan untuk menilai tingkat kesesuaian penyajian informasi keuangan terhadap panduan yang telah ditetapkan yaitu prinsip akuntansi yang berterima umum. Proses tersebut dilakukan oleh orang yang memiliki keahlian yang memadai dan memiliki karakter yang netral dalam menjalankan proses audit. Informasi yang dikumpulkan ketika proses audit berlangsung, diantaranya termasuk informasi mengenai perusahaan dan 
Rahmawati \& Soeherman: Pengaruh Prospek Keuangan ...

lingkungannya, yang terdiri dari pengenalian internal, inspeksi dokumen transaksi, observasi asset, dan melakukan prosedur audit yang lain. Pada saat pelaksanaan rangkaian proses audit, auditor akan mengumpulkan bukti yang diperlukan yang dapat mendukung penyusunan audit report. Audit report merupakan laporan yang menyajikan opini auditor, yang menerangkan apakah laporan keuangan telah mengikuti prinisip akuntansi berterima umum. (Arens, Elder, Beasley, \& Hogan, 2017; Whittington, 2016)

Kebutuhan terhadap kegiatan audit dapat dipahami sebagai kebutuhan akan adanya akuntabilitas (pertanggungjawaban). Kegiatan ini umumnya dibutuhkan pada situasi usaha tertentu ketika pemilik bisnis menggaji orang lain untuk menjalankan bisnisnya, seperti yang terjadi pada bisnis modern saat ini. Pada lampau, sampai dengan awal abad 19, sebagian besar unit usaha berukuran relative kecil dan umumnya di miliki atau di operasikan dengan bentuk kepemilikan tunggal atau dalam bentuk kemitraan. Karena bisnis umumnya dikelola oleh pemiliknya langsung maka kesempatan untuk mendapatkan dana melalui pinjaman menjadi terbatas, karena informasi mengenai akuntabilitas yang berkaitan dengan pengelolaan perusahaan bagi pihak pemberi pinjaman sangat minim. Lahirnya konsep akuntansi modern dan auditing kemudian muncul pada masa revolusi industry, ketika perusahaan menjadi lebih besar dan membutuhkan tambahan modal untuk mendanai perluasan modal (William Jr, Glover, \& Prawitt, 2016).

Kebutuhan akan adanya rangkaian kegiatan audit, merujuk pada dua teori yang menjadi dasar dilaksanakannya rangkaian kegiatan audit, yaitu teori stewardship dan teori credibility. Dalam kedua teori tersebut di jelaskan bahwa akuntan public atau auditor menjalankan pekerjaan auditnya dengan mengedepankan kepentingan banyak pihak yang menggantungkan keputusan ekonominya dari pemaparan opini audit yang diterbitkan. Pemaparan opini audit akan dapat menambah kredibilitas dari informasi keuangan yang diterbitkan karena keberadaan opini audit menandakan bahwa laporan 
keuangan yang bersangkutan telah dinilai oleh pihak lain yang kompeten dan independen (Keay, 2017; Okpala, 2015).

Informasi keuangan yang berasal dari laporan keuangan yang diterbitkan secara umum, merupakan salah satu sumber informasi yang digunakan oleh para penggunanya untuk mendapatkan pemahaman mengenai semua keadaan perusahaan yang berkaitan dengan aktivitas bisnis, sumberdaya yang dimiliki oleh perusahaan serta prospek perusahaan di masa mendatang. Data mengenai prospek perusahaan yang disusun oleh manajemen akan sangat membantu para analis untuk mengurangi bias terhadap analisa prospek perusahaan dan menurunkan kemungkinan respon pasar yang underreaction terhadap pengumuman earning perusahaan di pasar modal. Data tersebut diharapkan dapat memberikan sumber informasi yang lebih informatif kepada investor untuk membuat keputusan (Zhang, Pei, \& Vasarhelyi, 2017)

Berdasarkan Pernyataan Standar Akuntansi 29, Opini dalam Audit Report terdiri dari lima jenis yaitu, opini wajar tanpa pengecualian, opini wajar tanpa pengecualian dengan paragraph penjelas, opini wajar dengan pengecualian, opini tidak wajar, dan menolak memberikan opini (Simamora \& Hendarjatno, 2019). Paragraph penjelas yang disertakan dalam opini audit akan muncul apabila terjadi tertentu yang dapat berpengaruh terhadap operasional perusahaan (baik itu kondisi tuntutan hukum, kondisi ekonomi yang berpotensi berpengaruh terhadap keberlangsungan operasional perusahaan, maupun kondisi lain yang berpotensi berpengaruh terhadap operasional perusahaan). Apabila terjadi suatu kondisi yang dapat berpengaruh pada keberlangsungan ekonomi perusahaan maka auditor harus menyertakan paragraph penjelas going concern pada opini auditnya.

Terdapat dua faktor yang dapat berpengaruh terhadap keputusan untuk diterbitkannya opini audit going concern, yaitu factor yang berasal dari 
Rahmawati \& Soeherman: Pengaruh Prospek Keuangan ...

perusahaan dan factor yang berasal dari auditor. Factor yang berasal dari perusahaan adalah factor yang berkaitan dengan prospek perusahaan kedepan, yang terdiri dari profitabilitas, likuiditas dan solvabilitas. Sedangkan factor yang berkaitan dengan auditor diantaranya terdiri dari karakter yang dimiliki oleh auditor, lamanya hubungan auditor dengan klien (audit tenure), dan ukuran kantor akuntan public yang melakukan audit (Brunelli, 2018).

Dalam proses penerbitan opini audit yang sesuai dengan kondisi ekonomi perusahaan yang bersangkutan, diperlukan pemahaman dan pengetahuan yang memadai berkaitan dengan kegiatan ekonomi utama perusahaan. Dalam hal penerbitan opini audit yang berkaitan dengan keberlangsungan perusahaan (opini audit going concern), pengetahuan mengenai siklus ekonomi dari perusahaan yang bersangkutan bisa didapatkan dari informasi rasio keuangan yang berkaitan dengan prospek perusahaan kedepan dan juga bisa didapatkan dari lamanya hubungan perikatan antara auditor dengan klien yang bersangkutan (Praptika \& Rasmini, 2016; Robu \& Robu, 2015). Berdasarkan penjelasan tersebut, maka penelitian ini bertujuan untuk menguji pengaruh prospek perusahaan dan audit tenure terhadap keputusan penerbitan opini audit going concern.

\section{TELAAH LITERATUR DAN PENGEMBANGAN HIPOTESIS}

\section{Stewardship Theory}

Stewardship Theory merupakan teori yang menitikberatkan pada pembahasan mengenai rasa percaya. Rasa percaya tersebut meliputi rasa percaya yang diberikan oleh pemilik perusahaan, rasa percaya terhadap profesionalisme, loyalitas dan kesediaan untuk mendahulukan kepentingan orang lain, dimana serangkaian rasa tanggung jawab adalah sesuatu yang relevan dengan Stewardship Theory. Dalam konteks audit, maka Stewardship Theory akan menekankan rasa tanggung jawab auditor tidak akan bertindak 
dengan mengutamakan kepentingan pribadi, tetapi akan bertindak dengan mengedepankan kepentingan banyak pihak. (Keay, 2017)

Pada dasarnya, Audit merupakan proses pemahaman terhadap informasi keuangan yang kemudian ditandingkan dengan prinsip akuntansi berterima umum dalam tujuan untuk menilai tingkat kesesuaian penyajian informasi keuangan terhadap panduan yang telah ditetapkan yaitu prinsip akuntansi yang berterima umum, yang ada akhirnya opini mengenai kesesuaian penyajian informasi keuangan terhadap prinsip akuntansi berterima umum akan di paparkan dalam laporan yang disebut sebagai Audit Report. Audit Report merupakan paparan yang disusun oleh auditor setelah menyelesaikan rangkaian proses audit, dimana laporan tersebut memuat opini independen yang mencakup kesesuaian perlakuan akuntansi terhadap prinsip akuntansi berterima umum. Selain memaparkan mengenai kesesuaian perlakuan akuntansi, Audit Report juga memaparkan kondisi ekonomi dari perusahaan yang bersangkutan. Apabila auditor kiranya menemukan adanya indikasi bahwa perusahaan dinilai akan mengalami kesulitan dalam mempertahankan kelangsungan hidupnya, maka auditor akan membuat paragraf penjelasan mengenai keberlangsungan perusahaan (Opini Audit Going Concern). Penerbitan opini audit yang sesuai dengan kondisi ekonomi perusahaan, merupakan kewajiban auditor sebagai pihak independen yang memiliki akses terhadap informasi internal perusahaan, dengan mengedepankan kepentingan banyak pihak yang menggantungkan keputusan ekonominya pada informasi ekonomi yang di paparkan oleh auditor yang bersangkutan (Arens et al., 2017).

\section{Credibility Theory}

Credibility Theory menjelaskan bahwa fungsi utama dari audit adalah untuk menambah kredibilitas dari informasi keuangan yang tersaji dalam 
Rahmawati E Soeherman: Pengaruh Prospek Keuangan ...

laporan keuangan. Dalam pandangan ini, auditor memiliki nilai lebih di mata kliennya dari kredibilitas yang dimilikinya. Laporan keuangan yang telah diaudit dipandang memiliki elemen yang dapat meningkatkan rasa percaya para pengguna informasi keuangan terhadap informasi yang tersaji dalam laporan keuangan yang telah disusun oleh pihak manajemen. Jika para pengguna informasi keuangan (misalnya, para pemegang saham, pemerintah, atau kreditur) membangun penilaian mereka berdasarkan informasi yang mereka terima, maka mereka harus memiliki keyakinan bahwa informasi yang mereka terima telah merepresentasikan nilai ekonomis perusahaan secara wajar. Rangkaian kegiatan audit yang dilaksanakan diharapkan dapat mengurangi asimetri informasi antara manajemen dan para pengguna informasi keuangan. (Bobek, 2018; Munene, Njangiru, \& Ngungu, 2016; Okpala, 2015).

\section{Opini Audit Going Concern}

Audit Report merupakan laporan yang dibuat oleh auditor setelah selesainya proses audit. Audit Report menyajikan beberapa informasi penting yang diantaranya menjelaskan tentang kewajaran penyajian informasi keuangan serta penilaian terhadap kemampuan perusahaan untuk tetap mempertahankan aktivitas operasional utamanya (Going Concern). Situasi ini menempatkan auditor pada posisi penting karena auditor dipandang memiliki akses terhadap informasi internal perusahaan. Atau dengan kata lain Audit Report merupakan refleksi dari informasi internal perusahaan. Opini yang berkaitan dengan keberlangsungan perusahaan, salah satunya didasarkan pada informasi yang tersedia secara publik (contohnya informasi angka keuangan yang tertera pada laporan keuangan)(Robu \& Robu, 2015).

Berdasarkan Pernyataan Standard Auditing 29, opini auditor di kelompokkan menjadi lima jenis, yaitu : Opini wajar tanpa pengecualian, Opini audit wajar tanpa pengecualian dengan paragraph penjelas, Opini wajar 
dengan pengecualian, Opini tidak wajar dan Tidak memberikan opini (Simamora \& Hendarjatno, 2019).

Opini audit going concern merupakan opini audit yang diberikan oleh auditor kepada kliennya ketika auditor yang bersangkutan menemukan adanya kesangsian yang berkaitan dengan kemampuan perusahaan klien tersebut untuk mempertahankan kelangsungan usahanya (Simamora \& Hendarjatno, 2019; Tandungan \& Mertha, 2016).

\section{Prospek Keuangan Perusahaan}

Prospek keuangan perusahaan adalah proyeksi kemampuan perusahaan untuk menghasilkan profit atau pendapatan. Proyeksi tersebut bisa didapatkan dari data yang tersaji dalam laporan keuangan, yaitu dari perbandingan diantara data keuangan yang tersaji dalam laporan keuangan. Seara sederhana dapat dikatakan bahwa perusahaan yang secara keuangan dikategorikan sebagai perusahaan yang sehat adalah perusahaan yang berada dalam keadaan surplus. Dimana pendapatan operasional memiliki nilai yang lebih besar daripada beban operasional. Terdapat tiga rasio yang umum digunakan untuk mengukur prospek perusahaan yaitu : rasio profitabilitas, rasio likuiditas, dan rasio solvabilitas (Fatihudin \& Mochklas, 2018)

\section{Profitabilitas}

Konteks profitabilitas merujuk pada kemampuan entitas untuk mempertahankan profitnya dari tahun ke tahun. Kinerja profitabilitas mengindikasikan keberhasilan manajemen dan merupakan indicator kinerja yang paling penting bagi investor. perubahan terhadap profitabilitas akan berpengaruh terhadap perkembangan ekonomi, karena profit berpengaruh terhadap investasi dan keputusan mengenai penghematan anggaran dari perusahaan. Hal ini terjadi karena 
peningkatan dalam profit akan meningkatkan arus kas dari perusahaan dan membawa fleksibilitas perusahaan yang lebih besar dalam sumber pendanaan untuk kepentingan investasi perusahaan. Semakin besar akses terhadap fasilitas keuangan maka akan semakin besar kemampuan investasi untuk meningkatkan produktivitas. Dalam bahasa yang sederhana profitabilitas dapat ditafsirkan sebagai pengukuran kemampuan perusahaan untuk menghasilkan keuntungan (Return). Dimana keuntungan didapatkan dari pengurangan atas pendapatan usaha dikurangi dengan beban operasional (Ball, Gerakos, Linnainmaa, \& Nikolaev, 2015; Menicucci \& Paolucci, 2016).

Pengukuran profitabilitas perusahaan umumnya dapat dilihat dari Return On Asset perusahaan yang bersangkutan (Cherian et al., 2019; Martínez \& Rambaud, 2019; Robu \& Robu, 2015). Return on Asset dapat didefinisikan sebagai rasio keuangan yang digunakan untuk mengukur kemampuan asset perusahaan yang digunakan untuk melakukan operasional dalam menghasilkan keuntungan (Return). Rasio ini dihitung dengan membandingkan nilai keuntungan yang didapatkan oleh perusahaan terhadap total asset yang dimiliki oleh perusahaan. Semakin tinggi tingkat profitabilitas perusahaan maka akan semakin besar nilai dari rasio Return on Assetnya. Karena dengan nilai Return on Asset yang lebih besar maka menunjukkan bahwa dengan jumlah asset yang dimiliki, perusahaan dapat menghasilkan keuntungan yang lebih besar (Faizah \& Adhivinna, 2017; Hanif \& Bustamam, 2017)

Penelitian terdahulu mengenai pengaruh profitabilitas terhadap opini audit going concern menunjukkan adanya dua hasil yang berbeda. Hasil pemaparan dari penelitian golongan pada pertama memaparkan bahwa terdapat pengaruh profitabilitas berpengaruh negatif signifikan terhadap keputusan pemberian opini audit going concern pada perusahaan yang mengalami penurunan prospek keuangan (Hartono \& 
Wahyuni, 2017; Puspaningsih \& Analia, 2020; Ryu, Clifton, \& Roh, 2019). Sedangkan hasil pemaparan dari penelitian pada golongan kedua, memaparkan bahwa profitabilitas tidak berpengaruh signifikan terhadap keputusan pemberian opini audit going concern (Puspaningsih \& Analia, 2020; Yuliyani \& Erawati, 2017).

\section{Likuiditas}

Likuiditas adalah kemampuan perusahaan untuk membayar hutangnya secara segera setelah ditagihkan. Umumnya kewajiban yang dibayarkan adalah kewajiban yang bersifat jangka pendek (kewajiban yang berumur dibawah satu tahun)(Andy \& Megawati, 2019). Umumnya ketika pengguna informasi keuangan akan melakukan analisa likuiditas terhadap perusahaan tertentu, maka mereka akan memfokuskan diri pada informasi yang berasal dari laporan arus kas. Likuiditas dari suatu perusahaan dapat dilihat dari Current Rasio perusahaan yang bersangkutan. Rasio ini membandingkan asset lancar dengan kewajiban lancar. Asset lancar merupakan asset yang terdiri dari kas dan setara kas yang kemudian dibandingkan terhadap nilai kewajiban lancar dari perusahaan yang bersangkutan. Adapun nilai dari asset lancar umumnya didapatkan dari nilai kas pada tahun berjalan yang berasal dari perhitungan laporan arus kas dari perusahaan yang bersangkutan.

Current Ratio adalah pengukuran yang umum digunakan untuk mengukur likuiditas. Sebagaimana telah di jelaskan sebelumnya, rasio ini dihitung dengan membandingkan asset lancar terhadap kewajiban lancar. Ketika besaran angka keuangan pada laporan keuangan ditanggal tertentu bernominal sangat besar atau sangat kecil, maka situasi tersebut sangat mungkin tidak merefleksikan situasi yang wajar. Oleh karenanya Perbandingan jumlah asset lancar terhadap kewajiban 
Rahmawati E Soeherman: Pengaruh Prospek Keuangan ...

lancar, dinilai dapat mengatasi masalah ini. Current rasio merupakan gambaran kemampuan perusahaan untuk memenuhi kewajiban jangka pendeknya. Rasio ini mengukur kemampuan perusahaan untuk menghasilkan sumberdaya guna membayar hutang lancarnya. Semakin besar nilai current rasionya maka semakin besar tingkat likuiditas perusahaan (Kajananthan \& Velnampy, 2018; Kakati \& Roy, 2017; Zarb, 2018)

Penelitian terdahulu mengenai pengaruh likuiditas terhadap opini audit going concern menunjukkan adanya dua hasil yang berbeda. Hasil pemaparan dari penelitian golongan pada pertama memaparkan bahwa terdapat pengaruh likuiditas berpengaruh negatif signifikan terhadap keputusan pemberian opini audit going concern pada perusahaan yang mengalami penurunan prospek keuangan (Byusi \& Achyani, 2018; Ryu et al., 2019). Sedangkan hasil pemaparan dari penelitian pada golongan kedua, memaparkan bahwa likuiditas tidak berpengaruh signifikan terhadap keputusan pemberian opini audit going concern (Abadi, Purba, \& Fauzia, 2019; Puspaningsih \& Analia, 2020; Simamora \& Hendarjatno, 2019).

\section{Solvabilitas}

Rasio solvabilitas adalah rasio yang digunakan untuk mengevaluasi kemampuan perusahaan untuk membayar kewajibannya dalam jangka panjang. Pihak yang memberikan pinjaman, investor dan para pihak yang memberikan rating sangat memperhatikan kemampuan perusahaan untuk dapat memenuhi kewajiban operasionalnya. Rasio arus kas adalah rasio yang berguna untuk mengukur kemampuan perusahaan pada basis operasional yang sedang berlangsung. Rasio solvabilitas yang umum digunakan adalah perbandingan antara total hutang dibandingkan dengan total aset. Semakin tinggi nilai dari rasio 
ini, maka akan semakin rendah fleksibilitas keuangan dari perusahaan yang bersangkutan dan makin tinggi potensi perusahaan yang bersangkutan untuk mengalami gagal bayar. Dalam kata lain, semakin tinggi nilai rasio ini maka semakin buruk kemampuan operasional perusahaan untuk membayar hutangnya dengan menggunakan kas (Kajananthan \& Velnampy, 2018; Kakati \& Roy, 2017).

Penelitian terdahulu mengenai pengaruh solvabilitas terhadap opini audit going concern menunjukkan adanya dua hasil yang berbeda. Hasil pemaparan dari penelitian golongan pada pertama memaparkan bahwa terdapat pengaruh solvabilitas berpengaruh positif signifikan terhadap keputusan pemberian opini audit going concern pada perusahaan yang mengalami penurunan prospek keuangan (Achyarsyah, 2016; Ryu et al., 2019). Sedangkan hasil pemaparan dari penelitian pada golongan kedua, memaparkan bahwa solvabilitas tidak berpengaruh signifikan terhadap keputusan pemberian opini audit going concern (Rafflesia, 2015; Yuliyani \& Erawati, 2017).

\section{Audit Firm Tenure}

Audit Firm Tenure merupakan lamanya waktu yang di gunakan oleh kantor akuntan public dalam menjalankan perikatan dengan kliennya, dalam rangka menjalankan jasa audit laporan keuangan. Dengan kata lain audit tenure dapat didefinisikan sebagai rentang durasi hubungan antara auditor dan kliennya yang diukur dengan jumlah tahun lamanya perikatan yang berlangsung antara satu kantor akuntan public dengan satu klien yang sama. Ketika auditor memiliki penugasan dengan rentang waktu yang cukup lama terhadap satu klien yang sama, maka hal tersebut akan dapat menjadi memberikan peluang bagi auditor untuk memiliki pengetahuan bisnis yang lebih mendalam berkaitan dengan klien yang bersangkutan, sehingga hal 
tersebut akan memungkinkan auditor untuk dapat membangun program audit yang efektif agar dapat memberikan kualitas pengungkapan pada audit report yang memadai (Bell, Causholli, \& Knechel, 2015; Praptika \& Rasmini, 2016)

Penelitian terdahulu mengenai pengaruh audit firm tenure terhadap opini audit going concern menunjukkan adanya dua hasil yang berbeda. Hasil pemaparan dari penelitian golongan pada pertama memaparkan bahwa terdapat pengaruh audit firm tenure berpengaruh positif signifikan terhadap keputusan pemberian opini audit going concern pada perusahaan yang mengalami penurunan prospek keuangan (Bell et al., 2015). Sedangkan hasil pemaparan dari penelitian pada golongan kedua, memaparkan bahwa audit firm tenure tidak berpengaruh signifikan terhadap keputusan pemberian opini audit going concern (Puspaningsih \& Analia, 2020; Simamora \& Hendarjatno, 2019; Tandungan \& Mertha, 2016).

Bersandar pada penjelasan landasan teori diatas, maka kerangka pemikiran dalam penelitian ini dapat digambarkan sebagai berikut :

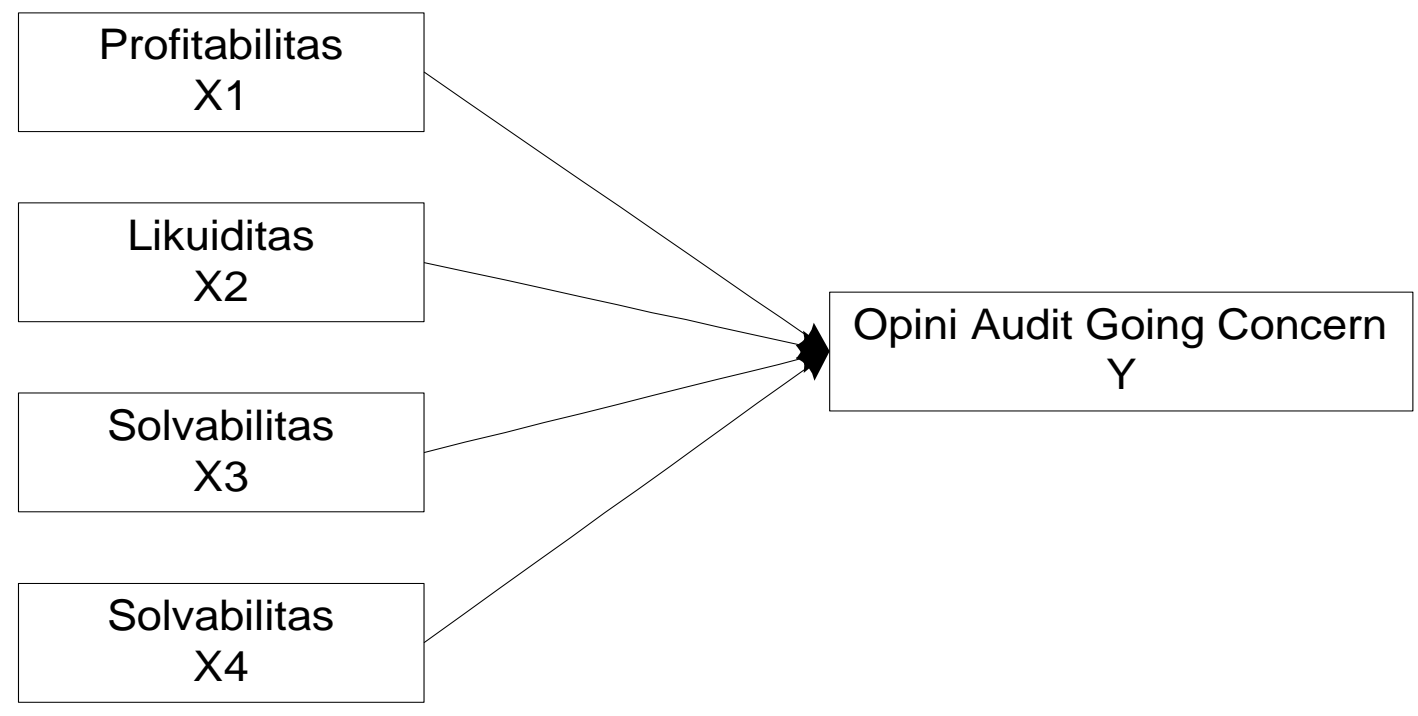

Gambar 1 Kerangka Pemikiran

\section{Hipotesis}


Berdasarkan penjelasan diatas maka pemaparan hipotesis dalam penelitian ini adalah sebagai berikut :

$\mathbf{H}_{\mathbf{1}}$ : Profitabilitas Berpengaruh negatif signifikan terhadap Opini Audit Going Concern pada perusahaan yang mengalami penurunan prospek keuangan

$\mathrm{H}_{2}$ : Likuiditas berpengaruh negatif signifikan terhadap Opini Audit Going Concern pada perusahaan yang mengalami penurunan prospek keuangan

$\mathrm{H}_{3}$ : Solvabilitas berpengaruh positif signifikan terhadap Opini Audit Going Concern pada perusahaan yang mengalami penurunan prospek keuangan

$\mathrm{H}_{4}$ : $\quad$ Audit Firm Tenure berpengaruh positif signifikan terhadap Opini Audit Going Concern pada perusahaan yang mengalami penurunan prospek keuangan

\section{METODE PENELITIAN}

\section{Jenis Dan Rancangan Penelitian}

Pendekatan penelitian yang digunakan dalam penelitian ini adalah pendekatan kuantitatif dengan metode statistik deskriptif. Pendekatan yang digunakan untuk menguji hipotesis penelitian adalah dengan menggunakan Regresi berganda (multiple regression) yang merupakan teknik yang dapat digunakan untuk menganalisis hubungan antara variable dependen dengan beberapa varaibel dependen. (Black \& Babin, 2019)

Penelitian ini merupakan penelitian eksplanatory yang menjelaskan hubungan pengaruh prospek keuangan perusahaan dan audit tenure terhadap keputusan opini audit going concern. Analisa regresi yang digunakan dalam penelitian ini adalah analisis regresi logistik karena skala data pada variabel 
Rahmawati \& Soeherman: Pengaruh Prospek Keuangan ...

dependen yang merupakan skala data kategorik yaitu opini going concern (kode 1) dan opini non going concern (kode 0 ). Hasil analisis regresi logistik dengan uji wald akan dijadikan dasar pengujian hipotesis.

\section{Populasi Dan Sampel}

Populasi dalam penelitian ini adalah perusahaan yang terdaftar di BEI pada tahun 2015 - 2018. Teknik pengambilan sampel dalam penelitian ini menggunakan metode purposive sampling, dimana sampel dalam penelitian ini adalah perusahaan yang terdaftar di Bursa Efek Indonesia selama periode 2014 - 2018 dan melaporkan laporan keuangan tahunan secara berturut-turut pada periode tersebut, serta mengalami tren penurunan kondisi keuangan.

\section{Definisi Operasional}

Definisi operasional variabel yang digunakan dalam penelitian ini adalah sebagai berikut :

1. Profitabilitas

Variabel profitabilitas dalam penelitian ini diukur dengan menggunakan Return On Asset. Rasio ini dihitung dengan membandingkan nilai keuntungan yang didapatkan oleh perusahaan terhadap total asset yang dimiliki oleh perusahaan.

2. Likuiditas

Variabel Likuiditas dalam penelitian ini diukur dengan menggunakan current ratio. Rasio ini dihitung dengan membandingkan asset lancar dengan kewajiban lancar. Asset lancar merupakan asset yang terdiri dari kas dan setara kas yang kemudian dibandingkan terhadap nilai kewajiban lancar dari perusahaan yang bersangkutan.

3. Solvabilitas 
Variabel Solvabilitas dalam penelitian ini diukur dengan menggunakan rasio solvabilitas. Rasio ini dihitung dengan membandingkan antara total hutang terhadap total aset.

4. Audit Tenure

Variabel Audit Tenure dalam penelitian ini diukur dengan menggunakan jumlah tahun lamanya perikatan kantor akuntan public melakukan audit pada klien yang sama

5. Opini Audit Going Concern

Variabel Opini Audit Going Concern dalam penelitian ini di ukur dengan menggunakan bilangan biner yaitu 0 dan 1 . Dimana angka 0 mewakili opini audit selain opini audit going concern dan angka 1 akan mewakili opini audit going concern

\section{Teknik Analisis}

Teknik Analisis hipotesis dalam penelitian ini menggunakan analisa regresi logistic dengan menggunakan uji wald. Sedangkan untuk pengujian keyalakan model regresi logistic, penelitian ini menggunakan Hosmer and Lemeshow's Goodness of Fit Test. Adapun persamaan regresi dalam penelitian ini adalah sebagai berikut :

$$
G C=a+b_{1} P R O F+b_{2} L I Q+b_{3} S O L V+b_{4} A T+\varepsilon
$$

Dimana :

GC = Opini Audit Going Concern

Prof $\quad=$ Profitabilitas

Liq = Likuiditas

Solv= Solvabilitas

AT = Audit Tenure

a dan $b=$ Koefisien Regresi

e $=$ Error 
Rahmawati \& Soeherman: Pengaruh Prospek Keuangan ...

HASIL PENELITIAN DAN PEMBAHASAN

Hasil pengujian regresi logistic untuk menguji hipotesis dalam penelitian ini digambarkan dalam tabel berikut ini :

Tabel 1

Hasil Pengujian Regresi Logistik

\begin{tabular}{lccccc}
\multicolumn{1}{r}{ Variabel } & Koefisien (B) & S.E & Wald & Sig & Exp (B) \\
\hline C & $-0,402$ & 0,695 & 0,334 & 0,563 & 0,669 \\
\hline PROF & $-1,429$ & 2,373 & 0,363 & 0,547 & 0,239 \\
\hline LIQ & $-0,046$ & 0,034 & 1,781 & 0,182 & 0,955 \\
\hline SOLV & 1,901 & 0,650 & 8,547 & 0,003 & 6,693 \\
\hline AT & 0,036 & 0,226 & 0,025 & 0,874 & 1,036 \\
\hline AUD & $-3,106$ & 0,830 & 14,018 & 0,000 & 0,045 \\
\hline
\end{tabular}

Penjelasan dari paparan angka tabel hasil pengujian regresi logistic diatas, untuk pengujian hipotesis penelitian ini adalah sebagai berikut :

1. Pengaruh PROF terhadap Going Concern Opinion

Nilai koefisien regresi logitik variabel PROF adalah -1,429 dengan nilai exp (B) sebesar 0,239. Berdasarkan atas hasil ini dapat dikemukakan bahwa apabila perusahaan memiliki rasio profitabilitas (PROF) yang tinggi, maka peluang perusahaan untuk mendapatka opini audit going concern akan semakin kecil, dengan kemungkinan sebesar 0,239 kali dibandingkan perusahaan yang memiliki nilai rasio profitabilitas (PROF) yang rendah. Pengaruh dari variabel independen rasio profitabilitas (PROF) adalah tidak signifikan karena nilai signifikan yang diperoleh sebesar 0,547 yang lebih besar dari nilai signifikansi $5 \%$. Dengan demikian maka hipotesis 1 penelitian tidak terbukti. Hasil pengujian dari hipotesis ini mendukung penelitian yang dilakukan oleh Puspaningsih \& Analia (2020) dan Yuliyani dan Erawati (2017) bahwa profitabilitas tidak berpengaruh signifikan terhadap keputusan pemberian opini audit going concern. 
2. Pengaruh LIQ terhadap Going Concern Opinion

Nilai koefisien regresi logitik variabel LIQ adalah -0,046 dengan nilai exp (B) sebesar 0,955. Berdasarkan atas hasil ini dapat dilihat bahwa ketika perusahaan memiliki rasio likuiditas (LIQ) yang tinggi maka kemungkinan perusahaan untuk mendapatkan opini audit going concern akan semakin kecil, dengan peluang sebesar 0,955 kali dibandingkan perusahaan yang memiliki nilai rasio likuiditas (LIQ) rendah. Pengaruh dari variabel independen rasio rasio likuiditas (LIQ) adalah tidak signifikan karena nilai signifikansinya adalah sebesar 0,182 yaitu lebih besar dari tingkat signifikansi 5\%. Dengan demikian maka hipotesis 2 penelitian tidak terbukti secaa statistik. Hasil pengujian dari hipotesis ini mendukung penelitian yang dilakukan oleh Abadi, Purba \& Fauzia (2019), Puspaningsih \& Analia (2020), serta Simamora \& Hendarjatno (2019) bahwa likuiditas tidak berpengaruh signifikan terhadap keputusan pemberian opini audit going concern.

\section{Pengaruh SOLV terhadap Going Concern Opinion}

Nilai koefisien regresi logistik variabel SOLV adalah 1,901 dengan nilai exp (B) sebesar 6,693. Berdasarkan atas hasil ini dapat dikemukakan bahwa apabila perusahaan memiliki rasio solvabilitas (SOLV) tinggi maka peluang perusahaan untuk mendapatkan opini audit going concern akan semakin besar, dengan peluang sebesar 6,693 kali dibandingkan perusahaan yang memiliki nilai rasio solvabilitas (SOLV) rendah. Pengaruh dari variabel independen rasio solvabilitas (SOLV) adalah signifikan karena nilai signifikansi yang diperoleh sebesar 0,003 lebih kecil dari nilai signifikansi 5\%. Dengan demikian maka hipotesis 3 penelitian terbukti secara statistik. Hasil pengujian dari hipotesis ini 
Rahmawati \& Soeherman: Pengaruh Prospek Keuangan ...

mendukung penelitian yang dilakukan oleh Achyarsyah (2016) dan Ryu et al (2019) bahwa solvabilitas berpengaruh positif signifikan terhadap keputusan pemberian opini audit going concern.

4. Pengaruh AT terhadap Going Concern Opinion

Nilai koefisien regresi logitik variabel TENURE adalah 0,036 dengan nilai exp (B) sebesar 1,036. Berdasarkan atas hasil ini dapat dikemukakan bahwa semakin lama audit tenure (TENURE) maka peluang perusahaan yang mengalami tren penurunan ekonomi untuk menerima opini audit going concern akan semakin besar, dengan peluang sebesar 1,036 kali dibandingkan audit tenure (TENURE) perusahaan semakin singkat. Pengaruh dari variabel independen audit tenure (TENURE) adalah tidak signifikan karena nilai signifikansi yang diperoleh adalah sebesar 0,874 dimana nilai tersebut lebih besar dari nilai signifikansi 5\%. Dengan demikian maka hipotesis 4 penelitian tidak terbukti secara statistik. Hasil pengujian dari hipotesis ini mendukung penelitian yang dilakukan oleh Puspaningsih \& Analia (2020), Simamora \& Hendarjatno (2019), Tandungan \& Mertha (2016) bahwa audit tenure tidak berpengaruh signifikan terhadap keputusan pemberian opini audit going concern.

\section{SIMPULAN}

Hasil dari penelitian ini menunjukkan bahwa profitabilitas, likuiditas dan audit tenure ternyata tidak memiliki pengaruh signifikan terhadap keputusan pemberian opini audit going concern. Dari pengujian hipotesis dalam penelitian ini, ternyata yang memiliki pengaruh signifikan terhadap diberikannya opini audit going concern adalah tingkat solvabilitas atau tingkat kemampuan perusahaan untuk membayar seluruh hutang yang dimilikinya. Dari penjabaran tersebut, secara sederhana dapat dikatakan bahwa pertimbangan 
utama auditor dalam memberikan opini audit going concern (opini audit dengan paragraf penjelas mengenai keberlangsungan perusahaan) utamanya adalah dengan merujuk pada fleksibilitas keuangan perusahaan yang bersangkutan dalam hal kemampuan perusahaan untuk melunasi hutangnya. Semakin rendah kemampuan perusahaan untuk melunasi hutangnya maka akan semakin tinggi kemungkinan perusahaan untuk mengalami masalah keberlangsungan usaha dan semakin tinggi pula kemungkinan perusahaan tersebut untuk mendapatkan opini audit going concern.

Penelitian ini memiliki beberapa keterbatasan yaitu, penelitian ini dilakukan pada rentang waktu yang terbatas yaitu 2014-2018, sehingga tidak dapat dijadikan generalisasi untuk periode waktu sebelum rentang waktu sebelumnya. Selain itu, berdasarkan Brunelli (2018) faktor yang dianggap berpengaruh terhadap dikeluarkannya opini audit going concern tidak hanya terbatas pada prospek perusahaan dan audit tenure saja. Faktor ukuran kantor akuntan public dan karakteristik dari akuntan public juga berpengaruh terhadap keputusan untuk dikeluarkannya opini audit going concern.

Penelitian selanjutnya dapat melakukan penyempurnaan terhadap kekurangan dari penelitian ini dengan menggunakan variabel yang belum digunakan dalam penelitian ini seperti menggunakan karakteristik auditor yang bersangkutan atau menambahkan variabel ukuran kantor akuntan public untuk mendapatkan pengetahuan yang lebih luas. Selain itu penelitian selanjutnya juga dapat menambah rentang waktu penelitian untuk mendapatkan agar mendapatkan hasil pengamatan yang lebih akurat.

\section{DAFTAR PUSTAKA}

Abadi, K., Purba, D. M., \& Fauzia, Q. (2019). THE IMPACT OF LIQUIDITY RATIO, LEVERAGE RATIO, COMPANY SIZE AND AUDIT QUALITY ON 
Rahmawati \& Soeherman: Pengaruh Prospek Keuangan ...

GOING CONCERN AUDIT OPINION. Jurnal Akuntansi Trisakti, 6(1), 6982.

Achyarsyah, P. (2016). The Analysis of The Influence of Financial Distress, Debt Default, Company Size, and Leverage on Going Concern Opinion. IJABER, 14(10), 6767-6783.

Andy, A., \& Megawati, M. (2019). Analysis of Liquidity, Profitability and Solvency Ratios to Assess the Financial Performance of Companies in Cigarette Industries Listed on the Indonesia Stock Exchange. eCo-Fin, $1(1), 22-34$.

Arens, A., Elder, R., Beasley, M., \& Hogan, C. (2017). Auditing And Assurance Services, 16th Global Edition. Michigan: Pearson.

Ball, R., Gerakos, J., Linnainmaa, J. T., \& Nikolaev, V. V. (2015). Deflating profitability. Journal of Financial Economics, 117(2), 225-248.

Bell, T. B., Causholli, M., \& Knechel, W. R. (2015). Audit firm tenure, non-audit services, and internal assessments of audit quality. Journal of Accounting Research, 53(3), 461-509.

Black, W., \& Babin, B. J. (2019). Multivariate data analysis: Its approach, evolution, and impact The Great Facilitator (pp. 121-130): Springer.

Bobek, M. (2018). Nature of Audit and Demand for Audit. Český finanční a účetní časopis, 2018(1), 5-23.

Brunelli, S. (2018). Audit Reporting for Going Concern Uncertainty: Global Trends and the Case Study of Italy: Springer.

Byusi, H., \& Achyani, F. (2018). DETERMINAN OPINI AUDIT GOING CONCERN (Studi Empiris Pada Perusahaan Real Estate dan Property yang Terdaftar di BEI Tahun 2013-2015). Riset Akuntansi dan Keuangan Indonesia, 3(1), 13-28.

Cherian, J., Umar, M., Thu, P. A., Nguyen-Trang, T., Sial, M. S., \& Khuong, N. V. (2019). Does corporate social responsibility affect the financial performance of the manufacturing sector? Evidence from an emerging economy. Sustainability, 11(4), 1182.

Faizah, S. N., \& Adhivinna, V. V. (2017). Pengaruh return on asset, leverage, kepemilikan institusional dan ukuran perusahaan terhadap tax avoidance. Jurnal Akuntansi, 5(2), 136-145.

Fatihudin, D., \& Mochklas, M. (2018). How Measuring Financial Performance. International Journal of Civil Engineering and Technology (IJCIET), 6(9), 553-557.

Hanif, M., \& Bustamam, B. (2017). Pengaruh Debt To Equity Ratio, Return On Asset, Firm Size, dan Earning Pe Share terhadap Dividend Payout Ratio (Studi pada Perusahaan Manufaktur yang Terdaftar di Bursa Efek Indonesia Tahun 2011-2015). Jurnal IImiah Mahasiswa Ekonomi Akuntansi, 2(1), 73-81. 
Hartono, J., \& Wahyuni, S. (2017). Can backward-looking and forward-looking information debias the prospect effect in earnings announcements? Gadjah Mada International Journal of Business, 19(3), 227.

Kajananthan, R., \& Velnampy, T. (2018). Liquidity, Solvency and Profitability Analysis Using Cash Flow Ratios and Traditional Ratios: The Telecommunication Sector in Sri Lanka. Research Journal of Finance and Accounting, 5(23).

Kakati, S., \& Roy, A. (2017). A Study on the Financial Performance of Farmer Producer Companies with Special Reference to Northeast India. Amity Journal of Agribusiness, 2(1), 37-56.

Keay, A. (2017). Stewardship theory: is board accountability necessary? International Journal of Law and Management.

Martínez, M. d. C. V., \& Rambaud, S. C. (2019). Women on corporate boards and firm's financial performance. Paper presented at the Women's Studies International Forum.

Menicucci, E., \& Paolucci, G. (2016). The determinants of bank profitability: empirical evidence from European banking sector. Journal of financial reporting and Accounting.

Munene, L. W., Njangiru, M. J., \& Ngungu, S. W. (2016). Effect of Auditing on Financial Performance of Water and Sanitation Company in Kirinyaga County, Kenya. Journal of Finance and Accounting, 4(5), 271.

Okpala, K. E. (2015). Stamatis generic model and audit quality in Nigeria. The Journal of Social Sciences Research, 1(8), 94-101.

Praptika, P. Y. H., \& Rasmini, N. K. (2016). Pengaruh audit tenure, pergantian auditor dan financial distress pada audit delay pada perusahaan consumer goods. E-Jurnal Akuntansi, 2052-2081.

Puspaningsih, A., \& Analia, A. P. (2020). The Effect of Debt Default, Opinion Shopping, Audit Tenure and Company's Financial Conditions on Goingconcern Audit Opinions. Review of Integrative Business and Economics Research, 9, 115-127.

Rafflesia, Y. (2015). Pengaruh Likuiditas, Leverage, Debt Default, Firm Growth Dan Disclosure terhadap Opini Audit Going Concern pada Perusahaan Property dan Real Estate yang Terdaftar Di BEI Periode 2008-2013. Jurnal Akuntansi Unesa, 3(3).

Robu, M. A., \& Robu, I. B. (2015). The influence of the audit report on the relevance of accounting information reported by listed Romanian companies. Procedia Economics and Finance, 20(1), 562-570.

Ryu, T. G., Clifton, G., \& Roh, C.-Y. (2019). The effect of profitability and liquidity on audit opinions: An empirical analysis. Academic and Research Business Institute Journal Finance and Accountancy, Volume 25 July 2019. 
Simamora, R. A., \& Hendarjatno, H. (2019). The effects of audit client tenure, audit lag, opinion shopping, liquidity ratio, and leverage to the going concern audit opinion. Asian Journal of Accounting Research.

Tandungan, D., \& Mertha, I. M. (2016). Pengaruh komite audit, ukuran perusahaan, audit tenure, dan reputasi KAP terhadap opini audit going concern. E-Jurnal Akuntansi, 45-71.

Whittington, O., Ray. \& Pany, Kurt. (2016). Principles of Auditing and Other Assurance Service: New York: McGraw Hill.

William Jr, M., Glover, S., \& Prawitt, D. (2016). Auditing and assurance services: A systematic approach: McGraw-Hill Education.

Yuliyani, N. M. A., \& Erawati, N. M. A. (2017). Pengaruh Financial Distress, Profitabilitas, Leverage Dan Likuiditas Pada Opini Audit Going Concern. E-Jurnal Akuntansi Universitas Udayana, 19(2), 1490-1520.

Zarb, B. J. (2018). LIQUIDITY, SOLVENCY, AND FINANCIAL HEALTH: DO THEY HAVE AN IMPACT ON US AIRLINE COMPANIES'PROFIT VOLATILITY? International Journal of Business, Accounting, \& Finance, 12(1).

Zhang, L., Pei, D., \& Vasarhelyi, M. A. (2017). Toward a new business reporting model. Journal of Emerging Technologies in Accounting, 14(2), $1-15$. 